\title{
ECO-SERVICES AND THE ROLE OF FUNCTIONAL REGIONS IN SERBIA
}

\author{
BORISLAV STOJKOV AND MILICA DOBRIČIĆ
}

\author{
Phd Borislav Stojkov \\ retired University professor, present Director of Republic Agency for Spatial Planning \\ 10a Kralja Milutina Street, 11000 Belgrade \\ E-mail: borislav.stojkov@rapp.gov.rs \\ MSc Milica Dobričić \\ Senior planner in the Republic Agency for Spatial Planning \\ 10a Kralja Milutina Street, 11000 Belgrade \\ E-mail: milica.dobricic@rapp.gov.rs
}

\begin{abstract}
The new idea of functional regions has been interpreted in alignment with the idea of functional urban areas in the Serbian planning discourse and practice. The new Spatial Plan of Serbia introduced the idea in compliance with the Law on Regional Development and statistical nomenclature of regions NUTS2 and districts NUTS3 in Serbia. The functional region is understood and presented as a cluster of municipalities organized flexibly around some important project(s) with a proper (sub) regional institution in charge of spurring and realizing the same. The problem is with clustering municipalities i.e. understanding the role and meaning of it for their joint interest, with some political reasons and lack of awareness as the main reasons for that.

On the other hand the list of strategic priorities has been prepared for all functional regions. The list contains projects for economic, social and ecological development. Eco-services are among the high priority issues but asking for intensive horizontal coordination and clustering a group of interested municipalities. Regional landfills, waste water purification, protected nature (high mountains) use, small rivers cleaning, are among such projects with some hot spots eliminating as paramount ones. Activating all stakeholders in the implementation phase is permanent duty of planners and administration, with possible economic measures to be pursued by the state. Eco-services are under intensive surveillance of the state administration in the phase of adapting its legislative to EU membership with an expected transfer of duties and jurisdiction to local communities (municipalities and cities). Vertical coordination with regions and the state is therefore a must for municipalities in this phase of development of Serbia.

The illustrations will be presented for better understanding the initial position of functional regions in Serbia and the position of eco-services in the future of local communities clustering.
\end{abstract}

Key words: Functional regions, eco-services, strategic priorities, joint interests, clustering 


\section{INTRODUCTION}

Functional regions and their practical meaning is one of new ideas in the Serbian legislation ${ }^{1}$ but without necessary explanations and implementation in the context of territorial organization of the country. Several questions rise out of it but two major ones are: (1) what functional region (oblast) really means, (2) what is the difference between functional regions and functional urban areas as defined in the new Spatial Plan of Serbia ${ }^{2}$. This is not only the case of Serbia but also of other Central-European countries in transitional process from centralized and unitary to decentralized and regionalized territorial and administrative system. In Bulgaria, as an EU member country, "the district is de-concentrated state administration unit responsible for implementing the government's policy at regional level" (Spiridonova, 2011), similar to Serbia as a non-member country. The Romanian case is different with counties as "administrative-territorial units situated immediately below the state as chosen authority of public administration and having their own financial means" (Popescu, 2011). Croatia, similar to Serbia, introduced counties in their legislative as statistical units only. The new terms introduced in course of approaching to EU legislative and political systems have been defined without ample experience and necessary theoretical discourse. The formal reasons have been prevailing and practical consequences have not been visible enough. The planning practice in these countries had different standpoints, more informed and bred on their past experiences and applying some ideas without substantial understanding of their meanings. The discrepancy between legal system and planning practice in Serbia is paradigmatically obvious with different interpretations of counties (oblast), i.e. statistical versus functional territories.

On the other side eco-services are still present in Serbia as an idea in theoretical discourse only. The legislative and planning practice do not recognize the term and its meaning for the future development, population or eco-systems destinies and the nature prospective in general. The first attempts with EMERALD network already established and NATURA 2000, as expected to be completed until 2014, are still initial endeavors of the state administration without vertical coordination to local and regional tiers and without proper horizontal coordination among local communities as key-players in the game of protecting and enhancing ecological systems and the nature as a whole. The planning ideas in a number of regional and local spatial plans and strategies ${ }^{3}$ have no adequate instruments to be effectively implemented in the post-planning phase. Many of them refer to eco-systems and the nature, listed either as planning visions or formal duties emerging from abundant new Serbian environmental legislative.

These two statements on functional regions and eco-services show that Serbia has hard duty to establish a functional model that would enable systematic eco-system protection and sustainable use engaging not only state administration capacities but also capacities of other tiers aware of ecosystems' benefits, with their resources and processes related to their economies and social systems.

1 The Law on Regional Development set a system of 5 statistical regions (European nomenclature of statistical units NUTS2) and 22 statistical counties (oblast) (NUTS3), without further explaining what oblast means except for statistics. The discussion about the role and meaning of oblast is actual at the end of 2011, with initial proposals that it means a functional cluster of interested municipalities around one of 22 official cities in Serbia, without legal or administrative subjectivity.

2 The Spatial Plan of Serbia 2010-2020 analyzed functionality of 22 cities and their surrounding areas, concluding that 64 $\%$ of the national territory is covered by functinal urban areas (FUA) in 2010 and the rest is without an urban center (city) asking for additional national efforts to support their development by the means of particular projects.

3 The effort of the spatial planning ministry with state and local agencies in Serbia has resulted with 9 regional and 144 municipal and city (municipality with more than 100000 inhabitants) spatial plans, thus covering the whole state territory in 2011. 

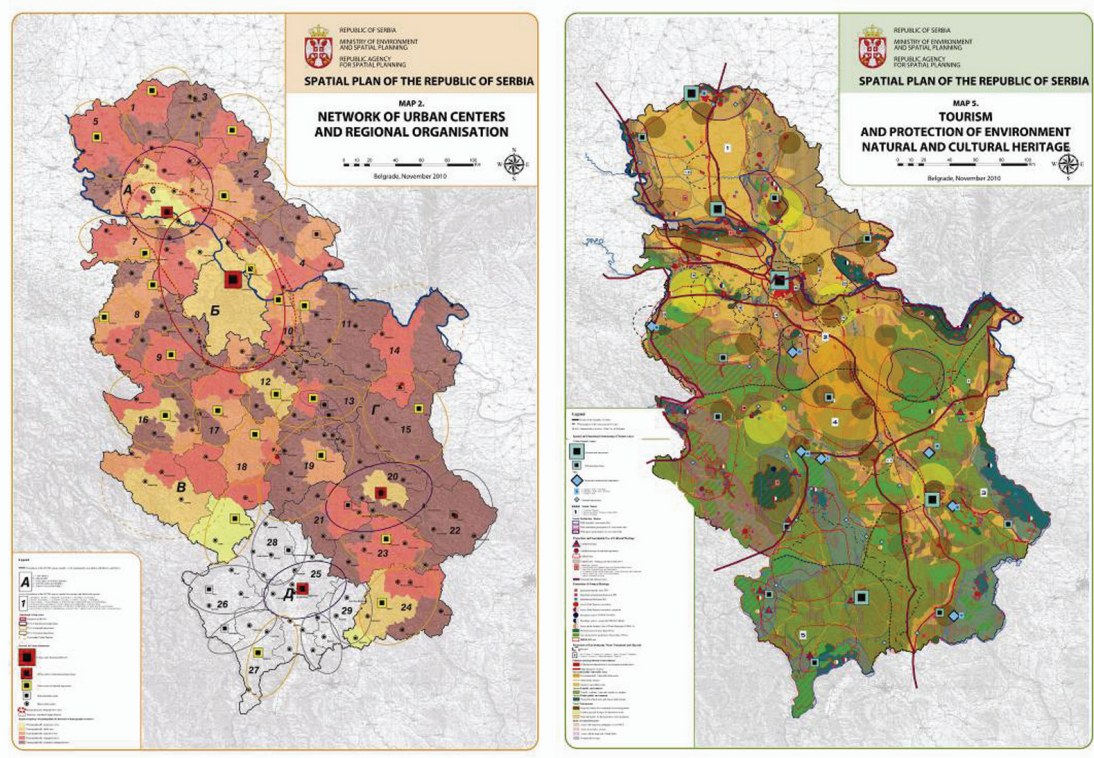

Figure 1. Functional urban areas and eco-systems maps in the Spatial Plan of Serbia 2010-2020 (Source: Spatial Plan of Serbia, 2010)

\section{ECOLOGICAL SERVICES AS A PRIORITY FOR SPATIAL DEVELOPMENT IN SERBIA}

Ecological services are relatively new idea in Serbian planning and administrative discourse and practice. Functional regions have been elaborated as one of basic development ideas in the future decentralized Serbia in the Law on Spatial Plan of Serbia (2010) and the Law on Regional Development of Serbia (2009). Both acts did not connected idea of municipalities clustering around eco-services but mainly around infrastructure endowment and some economic projects ${ }^{4}$. Nevertheless, maps from the Spatial Plan of Serbia evidently proof that eco-systems do not recognize border lines between neighboring local communities and even between countries but have their own natural, irresistible and irrefutable rules. In that sense ecosystem services are spontaneously becoming indispensable reason for local communities clustering. Local communities need to secure just use of eco-systems, coordinate interests of both the nature and people, and add to economic benefit of local communities, primarily in majority of underdeveloped rural communities in Serbia. These communities are dominantly located in mountainous and border areas of the country, where benefits like pure drinking water, abundant biodiversity, and resources for food, recreation and tourism are basic for their identity but completely underused or even misused in many cases.

In countries alike Serbia "ecosystem services are not fully 'captured' in commercial markets or adequately quantified in terms comparable with economic services and manufactured capital"” (Costanza et al., 1997) and therefore decision makers pay no attention to them while different players

4 In the draft version of the Law on Regional Development oblast (cluster of municipalities) was named as economic region and in some theoretical papers as functional region or nodal region in former times. 
use them for their, often illegal, activities. As a result eco-system owners, i.e. owners of resources (Law on Public Ownership, 2011) in a particular local community, have immeasurable costs while users having benefits out of it without compensating collateral costs adequately. As an example, the water accumulation is covering $35 \%$ of the territory of the Knic municipality plus protection area around, with all development restrictions coming out of the legal framework, and the city of Kragujevac is using it for potable water supply to its 215000 inhabitants and a large industry with no economic costs covering. The water as one of provisioning eco-services is generally neglected issue in Serbia and Djordjevic concludes that "our wish to provide precious water, to protect people of floods, and enable people to enjoy around river coasts, we have to operate with ethics of responsibility only" (Djordjevic, 2010). In spite of relatively limited resources in the country, the water as a multifunctional resource is usually treated as mono-functional giving advantage to one sector only. With availability of its own surface waters Serbia is among poor water areas in Europe with ca $1500 \mathrm{~m} 3$ per inhabitant annually, and with spatial unevenness of waters where some mountainous areas to the South have ca $30,0 \mathrm{~L} / \mathrm{sec} / \mathrm{km} 2$ and some plain areas to the North less than $1,0 \mathrm{~L} / \mathrm{sec} / \mathrm{km} 2$ in average. The time evenness is also lacking with $60-70 \%$ of annual balance coming during torrents and long dry periods after a while, resulting with relation between minimal and maximal currents up to 1:2000 in some smaller rivers. Transit and underground waters are in similar situation. Ecological systems and biodiversity are final victims of such a situation. The weak vertical coordination between the state and local communities is contributing to the problem of one of the most vital ecological system such as water, but lack of horizontal coordination between sectors using the water and local communities as owners or users is making the trouble even worse. Risks of endangering ecological services and biodiversity, generated by transforming many natural river currents into the network of channels and pipelines for mini-hydro plants (up to $10 \mathrm{MW}$ ), is the consequence of lacking vertical and horizontal coordination.

Historically, the territory of Serbia is one of the most important biodiversity centers not only in Europe but also in Western Pale-arctic zone. High mountain area of Serbia (the Balkan range) is one of six centers of European and one of 158 centers of the World biodiversity. The large ecosystem, species and gene diversity is characteristic of Serbia, albeit improperly used and with potential biological resources relatively limited. But "in spite of the long tradition of nature protection in Serbia the problem of disappearing important number of fauna and flora species is evident during last 20 years in particular" (Radovic, 2010). Low awareness of eco-systems importance, in terms of economy and social functioning, is producing biodiversity disappearing especially in the rural hinterland and mountainous area covering more than $40 \%$ of the territory of Serbia. Thus, one of crucial supporting or habitat services is getting endangered by non-systematic and non-sustainable treatment of the nature and its capacities, where the lack of local communities clustering has been noted.

With 5632 ha of agricultural land, covering $63.7 \%$ of the Serbian territory, this country has a number of problems with the soil use nowadays: wind and land erosion, use of inadequate agro-techniques, soil sealing and many socio-economic troubles connected with land ownership transformations. In the period after the year 2000 the agricultural land was diminished for 37000 ha in total. The problem of the soil use, as one of capital ecological systems, has been drastically neglected in the transitional phase aggravated by illegal constructing, uncontrolled land ownership, weakening agriculture as activity, depopulation processes and the like. The weak inter-sectoral cooperation, and missing public/private development programs on national, regional and local tiers, threatens one of the most significant ecological resources of Serbia and food benefits out of it. The low awareness of the fact that "natural resources are not invulnerable and infinitely available" (Wikipedia 
2011), in spite of the new legislative in Serbia, asks for active and effective measures to save the soil for the future of the country. The soil is increasingly and almost dramatically attracting attention of new investors, around big cities in particular, especially where this natural element is crucial factor of development. The soil is progressively increasing interest among agro-producers on one hand side but also among investors with their greenfield investment ideas on the other side. For former ones it is a matter of their existence and for later ones it is subject of profit making, still cheap and easy to afford, not forgetting the fact that existence and profit could be mutually dependent. The ambivalent meaning and use of the soil is dramatically appearing during the period of transition in Serbia where the new value system has not been established properly and where greenfield investments are of key development importance. The obvious situation in this country is illustrated by harsh attacks to the soil (greenfields) pursued by liberal market forces, confronted with societal framework with no proper value system, weak legislative instruments and corruptive administration. In such a socio-economic context the soil, as crucial eco-system with its multifunctional services, is practically victim of new economies and missing understanding that the soil as an eco-system is being disposed over municipalities' borders where diverse and conflicting local policies and interests can jeopardize its valuable services.

All the eco-systems in Serbia are under careful surveillance in legislative and planning frameworks. A number of legal acts have already been adopted, institutional system has been re-established and plans and strategies completed. One of the most significant planning acts is the new Spatial Plan of Serbia, with precise analyses of eco-systems and with objectives, concepts and strategic projects incorporated within it.

As for waters the basic goal is integral protection and use of waters on the whole national territory. This means realizing multifunctional use of hydro-economic systems, in harmony with environment and adapted to other natural and functional systems. This practically means harmonizing hydro-economic, ecological and other development objectives with the hydro-economic space as a whole of the territory of Serbia. The soil is treated as a multifunctional resource and the policy is oriented towards protecting its eco-systemic, agro-ecological, economic, socio-cultural functions, simultaneous with enhancement of spatial heterogenous conditions for agro-production and food. For this policy the set of objectives relates to: land use control, erosion control and diminishing, elimination of noxious impacts of traditional agriculture, supporting production of healthy food, pursuing soil recultivation and revitalization, developing active inter-sectoral cooperation and other issues. The biodiversity is getting high priority among national policies in Serbia with special attention given to sustainable use of biological resources measured by several criteria such as: sustainability of biological resources, the quantity of biological resources, exploitation of biological resources, sensitivity of biological resources and their renewability. Finally, high mountain areas should be protected and developed by the means of functional and spatial integration or clustering of local communities around each mountain and its development strategy implementation.

The new policies and strategies will ask for dynamic activity of scientific, administrative and professional institutions as well as awareness raising among people especially over rural areas of Serbia. In any case, one issue is becoming of utmost importance for the future of mentioned eco-services: the role of functional regions, i.e. meaning of clustering local communities around eco-system issues, their protection, use and development. 


\section{FUNCTIONAL REGIONS AND THEIR ROLE IN DEVELOPING ECO-SERVICES IN SERBIA}

The new legislation on regional development of Serbia, introducing the idea of regions and statistical regionalization, defined two types of regions: macro-regions (region) and districts (oblast). The definition of districts is not elaborated but usual interpretation is that district means functional region. Further interpretations go to several directions but the most important and feasible one is that district is not administrative unit but a sort of clustering local communities around common projects or interests. It is close to traditional definition of functional regions as "grouping municipalities by the criteria of common interests or flows of goods, people and communications between them" (Encyclopedia Britannica, 2011). Some theorists in Serbia are using classical German or French theories explaining the notion as "nodal region" (Veljkovic, 1991) or "functional nodal region" as a region where a number of places is linked by communications or by organizing certain functions (activities) around an urban place. The statement that "nodal regions are defined by evaluating the external contacts of small areal units" (Nystuen and Dacey, 1961) is summarizing the notion with further explanation that "each of these areal units is assigned to that place with which it has the dominant association". The urban place is pivotal point and its functional surrounding is non-determined and fluctual. Functions, interests or even problems, expressed by some project(s), are influential factors to connect territorial units around the point. The common definition explains functional regions as "grouping municipalites by the criteria of common interests or flows of goods, people and communications between them" (Encyclopedia Britannica, 2011). Of particular meaning is the notion that functional regions are flexible and dynamic, as much as interests or flows are dynamic and flexible. In terms of that Nystuen and Dacey point out that "direction and magnitude of flows associated with social processes are indicators of spatial order in the regional structure... The notion of nodal point is dependent upon the levels of strongest association within the total flows" (Nystuen and Dacey, 1961). This definition is fifty years old but still valid in general terms and applicable in situations such as in Serbia nowadays.

The notion of functional regions asks for better understanding the role of local community, i.e. endeavours of people at the lowest tier of governing, who has its problems and interests unable to solve or capitalize them without either networking with other communities for achieving higher level of capacity to do it (professional, institutional, financial) or asking the national center to do it for them. The situation in Serbia is paradigmatical with the state slowly shifting from centralized to decentralized political system but not yet in total. Local communities are still looking to the national center (government) to solve all their problems, to realize local projects or to support any of their interests, in spite of some new given instruments such as fiscal decentralization or public ownership enacted by particular laws between 2007 and 2011. An explanation of nodal regions offered to students in Africa could be of use in such a situation: "Interactions (trade, communication) and not shared physical characteristics, define nodal regions. Regions are social constructs. They are created by humans to help organize, make sense of, and interpret human activity within a given geographic space" (Exploring Africa, 2011).

The most sensitive query and acute in Serbia is rising nowadays: How to pursue clustering of local communities in a country with inertia of centralized political system, when all tiers are still looking towards the national center? Majority of local communities (municipalities) are helpless and the state is helpless too and in such situation using partocratic criteria to help some of them. 


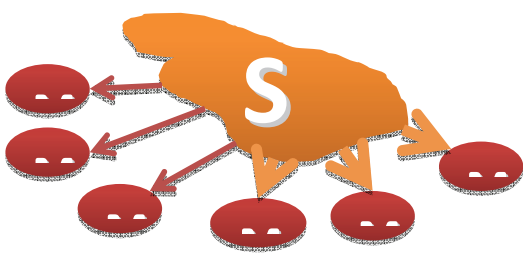

In centralized state

/ projects expected to be financed by state and priorities for political allies/

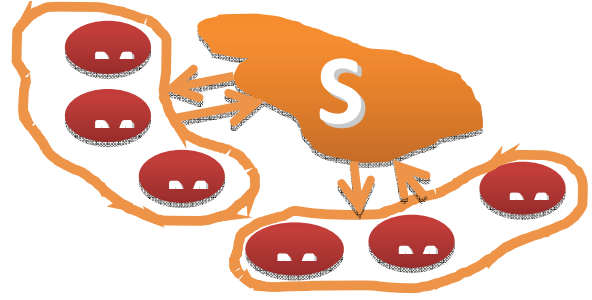

In decentralized state /different jurisdictions

and duties - a mutual support and expectations/

Figure 2. Different political systems' outputs

Local communities in Serbia have new development ideas launched by spatial plans in each of 122 municipalities and 23 cities, many of them spurring linkages with neighbours, but they look up to the national administration and the central budget for their implementation. The awareness of functional regions meaning and the advantage of clustering (networking) with neighbours is missing so far.

Networking as an dynamic activity, linking municipalities around joint projects in Serbia nowadays, could be treated as a mode of cooperation between interested parties to better and jointly use their resources, to realize some strategic project crossing over theirs borders or to solve some common problem where some have benefits and some have costs. Networking is an organizational instrument where some municiplities are jointly dependent upon resource(s) on their territories, and where they could have benefit(s) by pooling the resource(s). Municipalities should be aware of possible achieving important economic or social enhancement by means of networking but also of some possible costs for some of them. If we understand a functional region as "a territorial unit resulting from the organization of social and economic relations that is characterized by high frequency of intra-regional interactions" (Karlsson, 2007), than the performances of the unit should be calculated from the standpoint of different parties and their interests, benefits and costs. Also, the issue of network's sustainability should be taken into account with all expected internal (organization, financing, know-how) and external (legislative, technology advancement, market demands) threats and influences.

The appropriate reason for networking, emerging as one of spatial development priorities in Serbia, are eco-services, that is protecting and sustainably using ecological systems with their potential services to rural and lagging areas around big rivers, mountains, protected natural areas, etc. In the Spatial Plan of Serbia such areas have been registered with numerous projects listed as priority in the mid-term period between 2011 and 2015. Eco-services have been recognized as a form of direct or indirect interdependences between stakeholders interested in ecological issues but generally expecting positive externalities (benefits) out of it. For this reason functional regions, that is clusters of municipalities, around some ecological system, asks for prudent analysis to enlight the rationale of networking with all positive and negative (costs) externalities calculated. The necessary policies, organization, and financial and informatic models are indispensable to maintain long-term sustainability of such network and its permanent functioning. The acute problem in Serbia relates to pursuing municipalities to cluster for eco-services sustainably functioning.

The opportunities in Serbia during next mid-term period are under jurisdiction of national agencies related to raising awareness among municipalities on functional regions (oblast) meaning and importance, simultaneously with legislative improvement and completing. In each particular case municipalities have to be provided with basic information on all externalities, benefits and costs of 
networking, direct and/or indirect effects to employment and economic performances based on ecological enhancement, necessary horizontal and vertical linkages with adequate organization needed, dynamics of cluster and its consequences to each party in the project, possibilities of public-private partnership, etc. The existing strategies in the form of local spatial plans and their strategic-development dimension will be good foundation for networking municipalities. The intrinsic attention needs to be paid to the role of infrastructure as a public good determining the size of a functional region, and to the paramount role of urban center and its capacity to lobby for national and European funds. For this Konjar et al points out that "in centre-based delineation particular care needs to be taken in definition of the centres. While some countries identify centres according to the population or level of employment, others take account of commuting conditions" (Konjar, Lisec, and Drobne, 2010).

On the other side numerous constraints stand in front of implementing the idea of municipality clustering around eco-systems and their services in Serbia. Among them the low level of local infrastructure is crucial with weak accessibility as a result. The next are limited human resources in lagging areas, in terms of size, age and educational structures, and their capacity to handle and adequatly manage eco-projects in their public sector. The limited funds combined with lack of effective public (municipality) ownership, poorely implemented so far, is another constraint for municipality networking. Therefore the constraints imposed by negative externalities for a party (municipality, firm or individuals) and without adequate compensation are becoming unsurmountable treshold for a cluster's functioning. The agreement on internalizing one party costs is harsh task for any clustering attempt. The uncomplete information system in the national statistics of Serbia is also one of threats for the notion of clusters since the Census data are not classified on the county (oblast) level. Finally, the unclear legal status of counties, in the Law on Regional Development, and functional regions in the Law on Planning and Construction, is not able to pursue networking municipalities around eco-services or other development projects.

The list of eco-services, as one of priorities in regional development of Serbia, is rather long and it starts with regional solid waste disposal, regional systems for liquid waste purification, mountain areas protection and sustainable development, rivers and and other hydro-system resources, NATURA 2000 areas establishing, and others that have to bring Serbia to the higher level of environmental quality. The problems of human activities overusing or abusing natural resources over European standards, poluted environment in cities and even over rural areas and settlements, several hot-spots over Serbian territory, the nature biodiversity threatened in many cases, aggravate the goal of achieving $10 \%$ of the Serbian territory protected with higher standards until $2015^{5}$. The soil is "the ambivalent meaning and use of the soil is dramatically appearing during the period of transition in the countries where the new value system has not been established properly and where greenfield investments are booming, with people in rural hinterlands oriented to shifting from poor agriculture in former times to some new activities hopefully bringing fresh finances nowadays" (Stojkov, 2009).

Protected areas have highly important role in protecting eco-system services and biodiversity. According to Foley et al. (2005) the natural eco-systems are capable to support many services at high level of quality such as regulatung air quality, climate, water currents, forest production, habitat and biodiversity. The crucial step in establishing the mentioned services is formation of European Ecological Network NATURA 2000 (Biereznoj and Tripolszky, 2007), necessary to save natural systems and quality with all their services include. The diversity of eco-system's services offered by NATURA 2000 is enormous (Kettunen et al., 2009) with areas offering services of purifying and

\footnotetext{
${ }^{5}$ Serbia has $5.86 \%$ of its territory protected under the Law of Nature Protection in 2011
} 
maintaining water level in wet habitats, depositing carbon and controlling erosion or avalanshes. Besides, these areas provide services of recreation, education or eco-tourism, contributing also to local or regional identity. For implementing the ideas of NATURA 2000 and eco-system service the role of local communities and their possible networking is indispensable. Some examples in Serbia could enlight the problem in sequel.

\section{ECO-SYSTEMS IN SERBIA AND THEIR SERVICES}

Ecological systems have been theoretically treated as multifunctional in spatial development strategies of Serbia during few last years. It is close to the statement of Costanza et al. pointing that "ecosystem functions refer to the habitat, biological or system properties or processe of ecosystems" (Costanza et al., 2007). Functions and services offered by the systems are classified according to the UN Millennium Ecosystem Assessment (2005) as:

- Provisioning services - food, water, gene resources, natural medicins, biomass, fosile fuels, etc;

- Regulating services - services based on eco-system's capacities to regulate natural processes such as climate, air quality, water quality, erosion, etc;

- Supporting services - services needed as prerequisite for functioning all other services such as photosynthesis, nutrient and water cycling, soil formation, etc;

- Cultural services - non-material services coming out of saved ecosystems such as spiritual, aesthetical, recreative, educational, etc.

According to the Assessment ca $60 \%$, or 15 out of 24 global eco-system services are dilapitated, unsustainably or inadequately used, and natural and antropogenic factors influencing eco-system changes and their services could be direct (over-exploitation, invasive sorts, polution, climate changes, habitat changes) or indirect (demographic and technological changes, economic activities changes, socio-political-cultural factors). Consequently, "the soil is becoming a victim of the new dynamism and lack of proper understanding of its multifunctionality, eco-structure and substantial importance for the future of climate, food production or water capacity" (Stojkov, 2006).

Following the global and national situations Serbian administration understood that intrinsic policy changes, institutional advancement and practice enhancement, together with education, could diminish some of negative consequences and pressures to eco-systems over her territory. Naturally, different investments in environmental protection, education, health services and capacity building are necessary if expected results could be feasible in the near future.

Serbia has 463 protected areas to-day according to the state legislative with five national parks and 16 parks of the nature, covering $5,86 \%$ of the state territory. This is relatively small amount in relation to European criteria. The international status has been given to 10 areas registered on international lists, such as 9 RAMSAR sites and 1 Biosphere Reserve-UNESCO MaB, together with 42 Important Bird Areas (IBA), 61 Important Plant Areas (IPA) and 40 Prime Butterfly Areas (PBA) registered in the Law on Spatial Plan of Serbia. The basic conception of the nature protection is now oriented towards increasing the total area under protection up to $12 \%$, followed by establishing ecological networks of protected areas up to $20 \%$ of the state territory. The identification of areas for European ecological network NATURA 2000 will happen till the end of 2014. Realisation of these objectives should result with providing eco-services to different areas, enhanced local development as well as increased efficiency of protected areas management through adequate institutional arrangement and cooperation of different stakeholders. Numerous possibilities of networking local 
communities around common projects or functions of eco-services lead towards idea of functional sub-regionalization instead of administrative one. The possibility and constraints of clustering local communities on eco-system services will be ilustrated by an example out of several protected areas in Western Serbia, the river Uvac.

The protected area of the river Uvac is in the Soth-West area of Serbia, preliminary listed for European ecological network NATURA 2000 and identified as EMERALD, IBA, IPA and PBA area too. Covering 7543 hectars it is classified as 1 Category - special nature reserve. The protected area is encompassing parts of six municipalities lagging in development. The protected area offers numerous eco-system services such as pottable water and organic food provision, hydro-energy, spa resorts, beautiful landscape, gene resources, etc., but inevitably asks for the municipalities networking. The problem is in managing natural systems with each one controlled by different institutions. Sectors alike water, energy, forests, nature reserve and spa resort are directed by set of institutions with their mono-functional strategies, programmes and budgets, albeit the Spatial Plan for the area integrates them in the integrated strategic form but with no power to implement it properly. The lack of integrative regional institution in charge of clustering municipalities and coordinating eco-system's functions is more than evident.

Table 1. Eco-system services and functional region aspect around Uvac to-day

\begin{tabular}{|c|c|c|c|c|c|}
\hline ECO-SERVICES & USE & BENEFITS & COSTS & $\begin{array}{l}\text { INTER- } \\
\text { NALIZING } \\
\text { COSTS }\end{array}$ & $\begin{array}{l}\text { INSTITU- } \\
\text { TIONAL } \\
\text { ARRANG. }\end{array}$ \\
\hline $\begin{array}{l}\text { POTABLE } \\
\text { WATER } \\
\text { (provisioning } \\
\text { service) }\end{array}$ & $\begin{array}{l}\text { Part of regional } \\
\text { water system }\end{array}$ & $\begin{array}{l}5 \\
\text { municipalities }\end{array}$ & $\begin{array}{l}\text { Limited use of } \\
\text { pesticides; } \\
\text { high } \% \text { under } \\
\text { protection in } 1 \\
\text { municipality }\end{array}$ & $\begin{array}{l}\text { Compensa- } \\
\text { tion to rural } \\
\text { settlements; } \\
\text { water rent to } 1 \\
\text { municipality }\end{array}$ & $\begin{array}{l}\text { Directorate } \\
\text { for Potable } \\
\text { Water Use } \\
\text { Management }\end{array}$ \\
\hline $\begin{array}{l}\text { HYDRO- } \\
\text { ENERGY } \\
\text { (provisioning } \\
\text { service) }\end{array}$ & $\begin{array}{l}\text { Hydro-energy } \\
\text { plant }\end{array}$ & $\begin{array}{l}\text { National } \\
\text { energy system } \\
\text { and employ- } \\
\text { ment in } 6 \\
\text { municipalities }\end{array}$ & $\begin{array}{l}2 \text { muni } \\
\text { cipalities with } \\
\text { flooded soil }\end{array}$ & $\begin{array}{l}\text { No } \\
\text { compensation }\end{array}$ & HE Directorate \\
\hline $\begin{array}{l}\text { HEALTH } \\
\text { PROVISION } \\
\text { (provisioning } \\
\text { service) }\end{array}$ & Spa center & $\begin{array}{l}\text { Employ- } \\
\text { ment in } 2 \\
\text { municipalities }\end{array}$ & $\begin{array}{l}\text { Neutral in other } \\
4 \text { mun. }\end{array}$ & No & $\begin{array}{l}\text { Ministry } \\
\text { of Health }\end{array}$ \\
\hline $\begin{array}{l}\text { FLOOD } \\
\text { REGULAT- } \\
\text { ING (regulat- } \\
\text { ing service) }\end{array}$ & $\begin{array}{l}\text { Water } \\
\text { accumulation }\end{array}$ & $\begin{array}{l}3 \\
\text { municipalities }\end{array}$ & $\begin{array}{l}\text { Neutral in other } \\
3 \text { mun. }\end{array}$ & No & $\begin{array}{l}\text { National Water } \\
\text { System }\end{array}$ \\
\hline $\begin{array}{l}\text { GENE } \\
\text { RESOURCES } \\
\text { (supporting } \\
\text { service) }\end{array}$ & $\begin{array}{l}\text { White head } \\
\text { eagle } \\
\text { Plants }\end{array}$ & common & No costs & No & $\begin{array}{l}\text { Uvac Reserve } \\
\text { Office }\end{array}$ \\
\hline $\begin{array}{l}\text { AESTHETICS } \\
\& \\
\text { RECREATION } \\
\text { (cultural } \\
\text { service) }\end{array}$ & $\begin{array}{l}\text { River meander } \\
\text { Sustainable } \\
\text { tourism }\end{array}$ & $\begin{array}{l}\text { all munici- } \\
\text { palities and the } \\
\text { region }\end{array}$ & No costs & No & $\begin{array}{l}\text { Local } \\
\text { governments } \\
\text { and institutions }\end{array}$ \\
\hline
\end{tabular}


Clustering municipalities around eco-services delivers positive externalities (benefits) but for some parties negative (costs) too. The pottable water is the most important service for each of the municipalities but one of them will have costs due to the large protected areas (water sources and protected nature) on its territory. The discontent of particular municipality to-day is resulting from land use limitations and building restrictions but primarily from the lack of resource rent and compensations, that is internalizing costs for the negative externalities. Practically solving this problem would be one of main duties of the integrative institution, agreed and constituted at the level of a functional region. Other important duties would be: (1) educating population on the role and meaning of eco-services for their future economic development, (2) providing market for organic food and guaranteed income for producers, (3) defining rules for constructing and integrated constructions in the landscape, and (4) incorporating the idea of eco-services into tourist strategies with necessary standards in accomodation, food, facilities etc. This might contribute to employment, improving age structure and activating depleted and underused housing stock in rural areas.

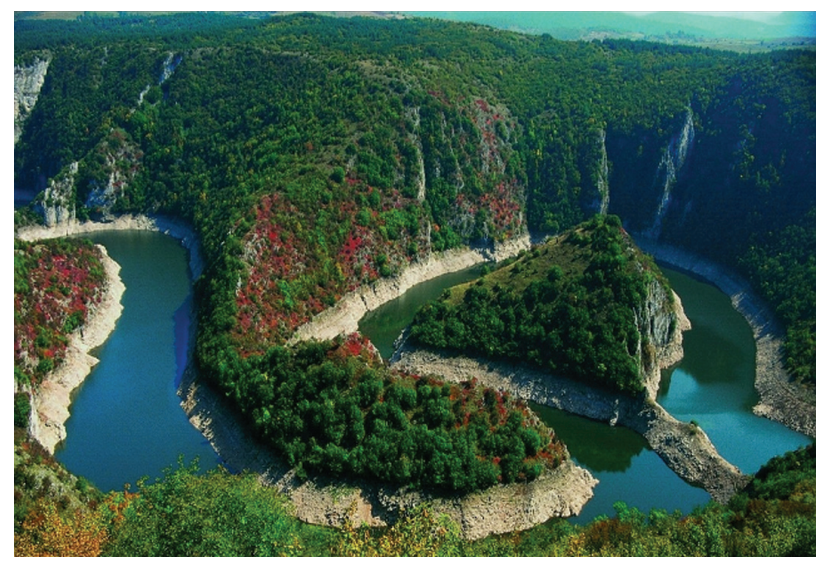

Figure 3. The river Uvac as natural phenomena and a multifunctional eco-system (Source: Uvac Special Nature Reserve 2011)

\section{CONCLUSION}

The basic aim of promoting functional regions from the standpoint of eco-services in Serbia is achieving sustainability of eco-systems and biodiversity resources in particular local communities (municipalities). The crucial objectives would be common benefits from eco-services for wider sub-regional areas, decreasing poverty rate, employing professional and working capacities in lagging areas, improving infrastructure endowment and general environmental enhancement. Specific tasks would relate to: (1) providing cooperation among local communities; (2) opening perspectives to cross-border cooperation; (3) establishing platform for effective partnership at local and regional tiers; (4) stimulating and contributing to better understanding the mutual interdependences between local biodiversity, decreasing poverty and sustainable development and (5) pursuing eco-systems menagement in sustainable mode ${ }^{6}$. This asks for prudent local and regional planning, connecting eco-systems with economic and social strategies and objectives, and active participation of stakeholders within the

${ }^{6}$ The education on eco-services is subject matter of Regional Center for Environment in CEE (REC) and their international offices in Serbia (REC 2011) 
planning and programming processes resulting with consensus on strategic objectives and expected results, positive and negative externalities included.

The overall situation in Serbia warns to serious internal and external threats that could jeopardize sustainability of local community networks. Internally the problems are low level of infrastructure quality, legislative weaknesses and lack of horizontal coordination between legal acts and offices, political (party) confrontations, and weaknesses in management capacities. Externally the problems are in following technological advancement, changes in demands for services and other external disturbances. But Serbia, with its natural and biological capital on one hand, and ultimate necessity to shift from local autarchy to modern governance and cooperation on other hand, will have to move towards an idea of functional regions as a mode orf effectively activate its regional territorial capital in a sustainable way. Eco-services could be a perfect reason for that.

\section{REFERENCES}

Biereznoj U., Sarolta T., 2007, Services of nature. CEEweb for Biodiversity, Budapest.

Costanza R., d'Arge R., de Groot R., Farber S., Grasso M., Hannon B., Limburg K., Naeem S., O’Neill R., Paruelo J., Raskin R., Sutton P., van den Belt., 1997, The value of the world's ecosystem services and natural capital, Nature 387:253-60.

Djordjevic B., 2010, Etika i hidroelektrane. Vijesti, Montenegrin daily newspaper, Podgorica.

Encyclopedia Britannica, 2011, (http://www.britannica.com/)

ExploringAfrica, 2011, Regional Perspectives, (http:/exploringafrica.matrix.msu.edu/teachers/ curriculum $/ \mathrm{m} 20$ )

Foley J., DeFries R., Asner G., Barford C., Bonan G., Carpenter S., Chapin S., Coe M., Daily G., Gibbs H., Helkowski J., Holloway T., Howard E., Kucharik C., Monfreda C., Patz J., Prentice C., Ramankutty N., Snyder P., 2005, Global Consequences of Land Use, Science 309:570-74.

Karlsson C., 2007, Clusters, Functional Regions and Cluster Policies, JIBS and CESIS, Electronic Working Paper Series, Paper No. 84.

Kettunen M., Bassi S., Gantioler S., ten Brink P., 2009, Assessing Socio-economic Benefits of Natura 2000 - a Toolkit for Practitioners, Institute for European Environmental Policy (IEEP), Brussels.

Konjar, Miha, Anka Lisec, and Samo Drobne. 2010. Methods for Delineation of Functional Regions Using Data on Commuters. University of Ljubljana, 13th AGILE International Conference, Guimaraes

Law on Nature Protection ("Official Gazette of the Republic of Serbia", No. 36/2009)

Law on Public Ownership ("Official Gazette of the Republic of Serbia”, No. 72/2011)

Law on Regional Development of Serbia ("Official Gazette of the Republic of Serbia”, No. 51/2009)

Law on Spatial Plan of Serbia ("Official Gazette of the Republic of Serbia", No. 88/2010)

Nystuen J., Dacey M., 1961, A Graph Theory Interpretation of Nodal Regions, Regional Science Association, Papers and Proceedings 7:29-42.

Popescu O., 2011, European Cities in Transition 2010, UN Habitat, National Report of Romania, Urban Development Institute, Krakow.

Radovic I., 2010, Biodiversity of Serbia, Spatial Plan of Serbia-Research and analytical basis, University of Belgrade, Belgrade. 
Regional Environmental Center for Central and Eastern Europe (REC) 2011. "REC Country Office Serbia” Retrieved December 20, 2011 (www.rec.rs)

Spatial Plan for the Special nature reserve Uvac ("Official Gazette of the Republic of Serbia", No. 95/2009)

Spiridonova J., 2011, European Cities in Transition 2010, UN Habitat, National Report of Bulgaria, Urban Development Institute, Krakow

Stojkov B., 2006, The Soil Use in Rural Areas, IP-SOIL II, Socrates-Erasmus Intensive Programme, Bodenkultur Universitaet, Vienna, Academia Danubiana 3:15-21

Stojkov B., 2009, Soil Use Pentagon, Faculty of Geography, University of Belgrade, Conference in Palic, Book of Proceedings 5:35-43.

UN Millennium Ecosystem Assessment, 2005, Ecosystems and Human Well-being: Synthesis. Island Press, World Resources Institute, Washington, DC.

Uvac Special Nature Reserve, 2011, Meanders, Retrieved September 28, 2011 (www.uvac.org. rs/en/meanders)

Veljkovic A., 1991, Gradovi-centri razvoja u mreži naselja Srbije, Geographical Institute "Jovan Cvijić", Book of Proceedings 43:161-96.

Wikipedia, 2011, Ecosystem services, Retrieved September 28, 2011 (http://en.wikipedia.org/wiki/ Ecosystem_services) 
http://rcin.org.pl 